\title{
Cyberbullying among secondary school teachers by parents
}

\author{
Rüyam Küçüksüleymanoğlu \\ Department of Educational Sciences, Uludağ University, Turkey
}

\begin{tabular}{l}
\hline \hline Article Info \\
\hline Article history: \\
Received Nov 17, 2018 \\
Revised Jan 20, 2019 \\
Accepted Feb 21, 2019 \\
\hline
\end{tabular}

\section{Keywords:}

Cyberbullying

Parents

Secondary school

Teachers

\begin{abstract}
Cyberbullying which is known as violence on the Internet is a dimension of peer bullying takes places through electronic communication technologies. Cyberbullying which can occur in any environment regardless of the time and place is the way in which individuals with higher ability to use communication technologies to lead other individuals in a series of negative behaviors over time. With the rapid development of technology and the ease with which internet access becomes easier and cheaper, it becomes a problem that needs to be studied more and more importantly day by day. Facebook, twitter and whatss up, the most widely used social network today, has the potential to become the most commonplace for cyberbullying behaviors. The purpose of this study was to determine cyberbullying towards teachers by parents in secondary schools based on teachers views according to sex, tenure and school size. The sample of the study was 181 teachers from 14 secondary schools. The experiences and perspectives of 181 teachers were assessed regarding the incidence and perceptions of the likelihood of cyber harassment by parents. The results presented here indicate that nearly $3 / 4$ of teachers in the sample had received harassing or threatening messages from parents.
\end{abstract}

Copyright $(2019$ Institute of Advanced Engineering and Science. All rights reserved.

\author{
Corresponding Author: \\ Rüyam Küçüksüleymanoğlu, \\ Department of Educational Sciences, \\ Uludağ University, \\ Gorukle Campus, Nilufer-Bursa, 16059, Turkey. \\ Email: ruyamk@uludag.edu.tr
}

\section{INTRODUCTION}

Bullying can be defined as an act of violence by an individual or group with the intention of hurting, a person physically (hitting him, or harming an item belonging to it), verbally (to ridicule an individual), sexually (to make inappropriate offers, or to send immoral content) and psychologically (to threaten or to humiliate him). Bullying affects more people every day and can be encountered at every moment of life. Today, bullying in schools is a serious and overarching issue that is bothering the public and governments day by day [1]. It is not possible to name all negative and aggressive behaviors that are applied to individuals as bullying. Taking into account the definitions in the literature, there are three main features of bullying in general. These are aggression, repetition and power imbalance [2]-[4]. In the case of bullying, individuals can be found in the status of bully, victim or bully-victim. While the oppressor is the one who is strong and the one who is acting, the victim is the relatively weaker side exposed to oppression. However a bull-victim is a person who is personally aggressive, who acts in a way that is likely to be tense with his social environment, and is sometimes the victim of the bullying, and sometimes the bully itself [5]-[8].

The advancement of technology and its availability as a bullying "tool" presented opportunities to make cyberbullying easier. The Internet offers benefits in terms of high-speed communication and information 
recall but, for many people, it also brings limitless, unchecked, and uncontrolled usage. Due to this freedom of use, coupled with a lack of defined limits, new form of bullying occured which is called cyberbullying that involves use of e mails, cellphones, pagers, whatss up messages, short message services, Internet chatrooms, blogs, forums, social network web sites, and cameras [9], [10]. Compared to traditional bullying, cyberbullying has some characteristics that can intensify the effects of bullying. Some of those; can be stated as the act of bullying can occur at any time and at any place, the perpetrator is mostly anonymous, it is generally noticed by others immediately. Studies related to cyberbullying show that cyberbullying and victimization have very serious negative effects on the social, academic and emotional lives of the individuals. Examples of cyberbullying have become a problem that affects more and more people, which need to be studied more today. [11]-[17]. Most of this research, however, has focused on issues associated with individual students or relationships between students (e.g., student bullies and student victims of bullying, aggressors and victims in student-on-student assaults), though some studies have examined attacks and threats against teachers from students [18]. A missing component in the school safety research concerns relationships and interactions between parents and teachers. Despite the important positive contributions made by parents in the school setting, parental aggression is a problem for teachers. Negative parental interaction has been cited as a source of undesirable occupational experiences for teachers [19]-[22]. Parents often communicate in demeaning, manipulative, threatening, and/or directly or passively aggressive ways with teachers. The vast majority of cyberbullying research has examined these problems primarily among students and left unexamined the impact of many of these school factors on teachers' perceptions and experiences. One largely overlooked area of research concerns cyberbullying from parents to teachers.

Schools currently use mobile technologies such as emails, text messages and whatss up as a primary or supplemental means to distribute information and proactively establish involvement of the parents [23, 24]. With this shift to ICT messages as a primary means of communication between parents and teachers, however, the impersonal nature of those messages may create additional opportunities for individuals to harass or threaten one another. The limited amount of existing research suggests that cyberbullying from parents is experienced by teachers both internationally and domestically. For instance, [25] found that some Canadian educators had been victims of text messages harassment, although they were more likely to be targets of verbal harassment. Later surveys of U.K.educators suggest that $15 \%$ to $20 \%$ of respondents had experienced a form of cyberbullying from parents via e mails, text messaging, or malicious websites [26]-[28]. Moreover, in 2009, one in five survey participants knew of colleagues who had been cyberbullied and had not reported it [26]. The findings also showed that cyberbullying had affected their work by reducing their confidence as a teacher; some were forced to take sick leave due to stress, at least some of which could be attributed to cyberbullying.

In general, researchers, policymakers, and practitioners have little information about the prevalence or incidence of cyberbullying toward teachers and situational and contextual factors associated with cyberbullying toward teachers. Thus, this study lays an important foundation for future work in this area by creating a baseline of knowledge regarding this topic that currently is limited in Turkey.

The purpose of this study is to determine cyberbullying towards teachers by parents in secondary schools based on teachers' views? For this purpose, the answers of the following questions were sought:

a. What kind of cyberbullying is being done by parents toward teachers in secondary schools by using ICT tools?

b. How often do parents cyberbully teachers with ICT instruments?

c. Do teachers' perceptions of cyberbully by parents change significantly according to their gender, tenure and school size?

The limitation of this study is that it focused solely on secondary school teachers' perspective working at Bursa, Turkey. Thus, although the findings presented here need to be taken in the context of this sample and are not immediately generalizable to the country as a whole, it is reasonable to expect that future research efforts with more representative samples would produce similar results.

\section{RESEARCH METHOD}

This descriptive research, measures the cyberbullying perceptions of the participants at a single time, with quantative research methods.

\subsection{Data collection}

As limited literature currently available on general parental cyber aggression toward teachers, it is understood that original items should be designed to help understand the types and responds of parental cyberbullying toward teachers at secondary schools. A focus group of experienced teachers, parents, and school administrators were used to develop the instrument. In the first part of the instrument type of cyber bully was

Int. J. Eval. \& Res. Educ. Vol. 8, No. 1, March 2019: 151 - 157 
asked to the teachers. Respondent teachers were asked if they had received any messages with ICT tools in the last 12 months that were (a) annoying; (b) embarrassing; (c) offensive; (d) insulting; (e) threatening; or (f) sexually suggestive. Respondents were asked about the frequency of cyberbullying on a scale from 1 to 5 where 1 means never and 5 means nearly everyweek The low mean scores on each of the variables are encouraging because they indicate that teachers rarely receive bullying messages. In the second part. What kind of responds do teachers use against cyberbully was asked with 7 choices. Information on the demographic characteristics of the teachers was collected by the "Teacher Information Form".

To begin the data collection process, an e-mail was mailed to all Nilüfer district secondary school administrators $(n=39)$ describing the purpose and methodology of the study and asking for the permission to send e-mails and whatss up messages to each teacher asking for their help in administering the instrument. The initial e-mail was followed up with two other e-mails and some visits to the schools. In the end, 14 (35.9\%) schools agreed to allow their teachers to participate. Once verbal consent was received from the principals, arrangements were made with teachers to give detailed information about the study. The schools returned the instrument in one week to the researcher.

The participants were 181 teachers working in the city of Bursa, Nilüfer district Turkey. Of these, $63.7 \%(n=93)$ were females and $36.3 \%(n=88)$ were males, of whom $11.6 \%(n=21)$ were less experienced than 5 years, $\% 40.9(n=74)$ were experienced between $6-14$ years, $47,5 \%(n=86)$ were more experienced than 16 years. $\% 35,7(n=5)$ of the teachers teach in schools with less enrollment than 500 students. $\% 64,3(n=9)$ of the respondents teach in schools with enrollments more than 500 students.

\subsection{Analysis of data}

The Shapiro-Wilk test was used to find out whether the data show normal dispersion or not. For the data showing normal dispersion, t-test and one-way analysis of variance were applied. For the variables that were found significant, Turkey HSD test was used to make comparisons across groups. For the data that did not disperse normally, Mann-Whitney $U$ was used. The relationships among the variables were investigated using with the co-efficient of Spearman correlation. The significant level was found to be $\alpha=0.05$. For the statistical analysis of the quantitative data, SPSS 16.0 was used.

\section{RESULTS AND DISCUSSION}

In this study, we define cyberbullying through type of messages, frequency of messages and responds of cyberbullied teachers. Respondents were asked to respond to questions asking them a parent of a child at their school had ever sent them cyberbullying messages with ICT tools.

$23 \%(n=43)$ respondontents reported that they have never been cyberbullied by parents in the last 12 months. More than half of those $(n=110 ; 79,7 \%)$, responding that a parent had sent numerous annoying $(n=83$; $60.1 \%)$, embarrasing $(n=65 ; 47.1 \%)$, offensive, $(n=91 ; 66 \%)$ posts. The number and percentage of other types of posts are as follows; insulting, $(n=57 ; 41 \%)$ and $(n=15 ; 10,8 \%)$ sexually suggestive messages.

Teachers reported that they receive $(\mathrm{X}=2.48)$ messages from parents with ICT tools in the last 12 months. These messages are mostly sent via SMS, whatss up and email. Afterwards, facebook phone talk and instagram are used by parents. Parents sending threatening $(X=3.29)$, annoying $(X=2.84)$, offensive $(X=$ 2.17) embarrasing $(X=2,39)$, insulting $(X=1,86)$ and sexually suggestive $(X=1,13)$ posts to the teachers respectively. (Table 1).

Table 1. Types of posts sent by parents

\begin{tabular}{ccc}
\hline Types of Posts & $\mathrm{X}$ & $\mathrm{Ss}$ \\
\hline Annoying & 2.84. & 0.74 \\
Embarrasing & 2.39 & 0.80 \\
Offensive & 2.17 & 0.69 \\
Insulting & 1.86 & 0.86 \\
Threatening & 3.29 & 0.99 \\
Sexually suggestive & 1.13 & 0.43 \\
Total & 2.48 & 0.64 \\
\hline
\end{tabular}

There were significant differences according to gender variable in relation to types of messages as seen in table 2 . The results indicated that female teachers had significantly more embarresing $(t=4.90, p=.04)$, insulting $(\mathrm{t}=2.77, \mathrm{p}=.00)$, and threatening $(\mathrm{t}=3.65, \mathrm{p}=.03)$ messages than their male counterparts. Although no significant differences were, found according to gender variable, the female teachers had more annoying $(X=2.72)$ and sexually suggestive $(X=2.12)$ posts where as male teachers get more offensive $(X=2.22)$ messages than the female.

Cyberbullying among secondary school teachers by parents (Rüyam Küçüksüleymanoğlu) 
Table 2. Teachers' gender and perception of cyberbully

\begin{tabular}{ccccc}
\hline & Gender & $\mathrm{X}$ & $\mathrm{t}$ & $\mathrm{p}$ \\
\hline Annoying & Female & 2.72 & 2.37 & .67 \\
& Male & 2.46 & & \\
Embarrasing & Female & 2.81 & 4.90 & .04 \\
& Male & 2.64 & & \\
Offensive & Female & 2.07 & 1.52 & .76 \\
& Male & 2.22 & & \\
Insulting & Female & 2.48 & 2.77 & .00 \\
& Male & 1.08 & & \\
Threatening & Female & 2.88 & 3.65 & .03 \\
& Male & 1.70 & & \\
Sexually suggestive & Female & 2.12 & .423 & .47 \\
& Male & 1.16 & & \\
\hline
\end{tabular}

The results in table 3 indicated that the teachers who are working between 6-14 years had significantly more offensive $(\mathrm{F}=6.28, \mathrm{p}=.03)$, posts than the teachers working over 15 years and less than five years. Furthermore, there are significantly differences among the less tenured and more than 15 years tenured teachers in case of threatening posts $(\mathrm{F}=6.93, \mathrm{p}=.02)$, The teachers with less experince have more threatening messages $(X=3.70)$. Although no significant differences were found according to tenure the less experienced teachers had more annoying, $(X=2.91)$ insulting $(X=2.48)$ and sexually suggestive $(X=2.12)$ posts than the more experienced colleouques. However teachers with 6-14 years tenure have more embarrasing $(X=2.81)$ posts than the others.

Table 3. Teachers' tenure and perception of cyberbully

\begin{tabular}{|c|c|c|c|c|c|c|}
\hline & Tenure & $\mathrm{X}$ & $\mathrm{F}$ & $\mathrm{df}$ & $\mathrm{p}$ & Significancy \\
\hline \multirow[t]{3}{*}{ Annoying } & $<5$ years $($ a) & 2.46 & 6.72 & 2 & .38 & \\
\hline & $6-14$ years $(\mathrm{b})$ & 2.72 & & & & \\
\hline & $>15$ years $(\mathrm{c})$ & 2.91 & & & & \\
\hline \multirow[t]{3}{*}{ Embarrasing } & $<5$ years $(\mathrm{a})$ & 2.64 & 3.58 & & .32 & \\
\hline & $6-14$ years $(b)$ & 2.81 & & & & \\
\hline & $>15$ years $(\mathrm{c})$ & 1.69 & & & & \\
\hline \multirow[t]{3}{*}{ Offensive } & $<5$ years (a) & 2.07 & 6.28 & & .03 & $a-b$ \\
\hline & $6-14$ years $(b)$ & 2.22 & & & & b-c \\
\hline & $>15$ years $(\mathrm{c})$ & 2.46 & & & & \\
\hline \multirow[t]{3}{*}{ Insulting } & $<5$ years (a) & 2.48 & 5.19 & & .58 & \\
\hline & $6-14$ years $(b)$ & 1.08 & & & & \\
\hline & $>15$ years $(\mathrm{c})$ & 1.03 & & & & \\
\hline \multirow[t]{3}{*}{ Threatening } & $<5$ years (a) & $3 ., 70$ & 6.93 & & .03 & $a-c$ \\
\hline & $6-14$ years $(b)$ & $2, .88$ & & & & \\
\hline & $>15$ years $(\mathrm{c})$ & $1 ., 39$ & & & & \\
\hline \multirow[t]{3}{*}{ Sexually suggestive } & $<5$ years (a) & 2,12 & 3,25 & & ,61 & \\
\hline & $6-14$ years $(b)$ & 1,06 & & & & \\
\hline & $>15$ years $(\mathrm{c})$ & 0,09 & & & & \\
\hline
\end{tabular}

As it is shown in table 4 the results indicated that the teachers who are working at crowded school with more than 500 enrollments had significantly more annoying, $(U=117.000, p=.04)$; offensive $(U=87.00$, $\mathrm{p}=.00)$ threatening $(\mathrm{U}=1533.00, \mathrm{p}=.02)$, and sexually suggestive $(\mathrm{U}=1566.00, \mathrm{p}=.04)$ posts than the teachers working in crowded schools. Although no significant differences were found according to the size of schools in crowded schools teachers have more embarrasing posts $(\mathrm{X}=2.81)$ whereas teachers in less crowded schools have more insulting $(\mathrm{X}=2.48)$ posts.

Table 4. School size and perception of cyberbully

\begin{tabular}{ccccc}
\hline & School Size & $\mathrm{X}$ & $\mathrm{U}$ & $\mathrm{p}$ \\
\hline Annoying & $<500$ & 2.46 & 1170.00 & .040 \\
& $>501$ & 2.72 & & \\
Embarrasing & $<500$ & 2.64 & 2810.0 & .076 \\
& $>501$ & 2.81 & & \\
Offensive & $<500$ & 2.07 & 2034.5 & .00 \\
& $>501$ & 2.22 & & \\
Insulting & $<500$ & 2.48 & 1265.5 & .084 \\
Threatening & $>501$ & 1.08 & & \\
& $<500$ & 1.70 & 1533.00 & .023 \\
Sexually & $>501$ & 2.88 & & \\
suggestive & $>500$ & 1.12 & 4016.5 & .011 \\
\hline
\end{tabular}

Int. J. Eval. \& Res. Educ. Vol. 8, No. 1, March 2019: 151 - 157 


\section{DISCUSSION}

The experiences and perspectives of 181 teachers were assessed regarding the incidence and perceptions of the cyber harassment by parents. The results presented here indicate that nearly $3 / 4$ of teachers in the sample had received harassing or threatening messages from parents. It is clear that cyberbullying and cyber harassment from parents is a problem for teachers in the sample. Internet provided a forum where parents would say things they wouldn't necessarily say face to face. There's no fear that they are going to get a punch in the head after they send posts on the internet. According to personal communication with an attorney, there are no laws that directly regulate cyber bullying in Turkey. Procedures applied in response to crimes committed on the internet, including cyber bullying, are regulated within the scope of law number 5651 on Regulation of Publications on the Internet and Suppression of Crimes Committed by means of Such Publications, which imposes obligations on parties (i.e., hosting service providers) running the virtual environments in which such crimes were committed. Because the current Turkish sanctions are not a disincentive for cyber bullies, it is necessary for lawmakers to enact more effective punishments and sanctions for this harmful behavior.

Parents mostly send threatening posts to the teachers. The most basic reason is unfortunately, in recent years people have become accustomed to use violence to make their wishes. In Turkey parents have the right to complain to the Ministry of Education by call center and to the president directly even in the smallest events. It is quite frightening and thought-provoking that the vast majority of society accepts the threattowards others as normal and ordinary.

Although some studies [29]-[34] report that gender is not related to cyber bully behaviors, the main findings of the present study were that female teachers had experienced more cyber bullying than males which is similar to [35] research. The findings of the present study related to gender is contradictory with, [36]-[39], who determined that male educators were significantly more likely to receive rude text posts than their female counterpart. Due to the cultural acceptance of women as weaker and vulnerable may have increased the violence against female teachers. The least cyberbullying type that their families apply is sexually suggestive. The main reason for this is that as culturally teachers are accepted "holly" sexually suggestive messages area highly immoral and unacceptable.

Teachers with 6-14 years of seniority receive annoying, embarrasing and offensive posts more than the others. Perhaps the most basic reason for this is that the teachers in this group are occupationally exhausted, and sometimes experience burnout syndrome. Because they are professionally exhausted, they may experience problems both in the teaching process and in communication within the classroom. This can also cause the parents to use cyber violence. Younger therefore less experienced teachers being more likely than their older counterparts to use social media and ICT tools [40], [41] and were also more likely to be victimized by cyber harassment. In the present study teachers with 5 years or less of seniority are young and inexperienced for the parents, and receive more insulting, thrilling and sexually suggestive posts. Probabaly parents see teachers as novice and defenseless. Because they think they can manage the teachers in this group more easily, they often cyberbully them. However, more experienced teachers develop strategies to better address student situations that might prompt cyber harassment than their less experienced counterparts [42]. Young teachers have difficulty in communicating with the parents especially the ones who are inexperienced and do not know how they are spoken to the family. While parents often treat their senior teachers more respectfully, they may find that inexperienced teachers are taught how to do their jobs, disrespectfulness, and arrogance.

Teachers working at schools with larger enrollments experience more cyberbullying from parents. The number of students enrolled in a school may contribute to cyberbullying of teachers because the larger student-to teacher ratios often found in these schools may result in less individualized attention from teachers and less interaction between parents and teachers in the course of the normal school year activities [43], [44]. Parents who feel their child is not receiving the treatment or attention they expect might be more likely to cyber-harass their teachers. This general lack of individual interaction may result in parents using technology to communicate with and possibly cyber-harass teachers, especially if they feel as though their child is not receiving enough personal attention. In addition, cyber bullying is more common in crowded schools because of the fact that parents have communication with each other and sometimes they have a bad influence on each other about the teachers and school functioning.

\section{CONCLUSION}

Proper communication between teachers and parents, whether about general policies or about a particular child's progress, is extremely important. Similarly, parents are often not provided with information on appropriate communication with teachers and thus may be unaware of the proper procedures to use for dealing with concerns about their children. Thus, it is imperative that parents learn these types of rules and guidelines on communicating with teachers and expressing their concerns when there is a problem. 
A review of the policies could take place during orientation at the beginning of each school year, parents should be given the policies in hard copy, policies should be available online, and policies should be revisited from time to time in media such as school newsletters, web sites and social media tools. There is a huge need for formal training in communication techniques that train teachers to reach out to parents in ways that prevent them from becoming aggressive or may help to de-escalate a parent who does become aggressive. Therefore, it is highly recommended that educators receive specialized training courses and/or refreshers in communicating with parents as part of the continuing education or in-service training

This exploratory study has offered some insight into the levels of parental harassment experienced by Turkish teachers. There are, however, some limitations to this study that limit the generalizability of these findings and should be addressed in future research. Future research will utilize probability samples with more diverse groups of respondents so that results can be generalized to the larger population of educators.

\section{REFERENCES}

[1] Gladden, R. M, Vivolo-Kantor, A. M, Hamburger, M. E, \& Lumpkin, C. D, "Bullying surveillance among youths: Uniform definitions for public health and recommended data elements, version 1.0," Atlanta, GA: National Center for Injury Prevention and Control, Centers for Disease Control and Prevention, 2014.

[2] Volk A. A, Veenstra R., Espelage D. L., "So you want to study bullying? Recommendations to enhance the validity, transparency, and compatibility of bullying research," Aggress. Violent Behav, vol. 36, pp. 34-43, Retreived from 10.1016/j.avb.2017.07.003, 2017.

[3] Hinduja, S., \& Patchin, J. W, "Bullying beyond the schoolyard: Preventing and responding to cyberbullying," Available from Carwin Press. http://books.google. com/books, California 2009.

[4] Ybarra, M., West, M. D., \& Leaf, P, "Examining the overlap in Internet harassment and school bullying: implications for school intervention," Journal of Adolescent Health, vol 41, pp. 42-50, 2007.

[5] Watts, L. K, Wagner, J, Velasquez, B, \& Behrens, P. I, "Cyberbullying in higher education: A literature review," Computers in Human Behavior, vol 69, pp. 268-274, 2017.

[6] Lacey, B, "Social aggression: a study of internet harassment," Unpublished Doctoral Dissertation, Long Island University, 2007.

[7] Willard, N, "Cyberbullying and cyberthreats. Available from," U.S.A: Research Press, http://books.google.com/books. 2007.

[8] Raskauskas, J. and Stoltz, A. D, "Involvement in traditional and electronic bullying among adolescents," Developmental Psychology, vol 43, pp. 564-575, 2007.

[9] Deschamps, R. and McNutt, K, "Cyberbullying: What's the problem?," Canadian Public Administration, vol 59, pp. 45, 2016.

[10] Calvete, E., Orue, I., Estévez, A., Villardón, L., \& Padilla, P, "Cyberbullying in adolescents: Modalities and aggressors' profile," Computers in Human Behavior, vol 26, pp. 1128-1135, 2010.

[11] Cornell, D. G. and Mayer, M. J, "Why do school order and safety matter?," Educational Researcher, vol 39, pp. 7-15, 2010

[12] Flannery, D. J., Wester, K. L. \& Singer, M. I, "Impact of exposure to violence in school on child and adolescent mental health and behavior," Journal of Community Psychology, vol 32, pp. 559-573, 2004.

[13] Buhs, E, Ladd, G, \& Herald, "Peer exclusion and victimization: Processesthat mediate the relations between peer group rejection and children's classroomengagement and achievement," Journal of Educational Psychology, vol 98, pp. 1-13, 2006.

[14] Nishina, A., Juvonen, J. and Witkow, "M. R, Sticks and stones may break mybones, but names will make me feel sick: The psychosocial, somatic, and scholasticconsequences of peer harassment," Journal of Clinical Child \& Adolescent Psychology, vol 34, pp. 37-48, 2005.

[15] Flannery, D. J, Wester, K. L. \& Singer, M. I, "Impact of exposure to violence in school on child and adolescent mental health and behavior," Journal of Community Psychology, vol 32, pp. 559-573, 2004.

[16] Ladd, G. W, "Probing the adaptive significance of children's behavior andrelationships in the school context: A childby-environment perspective. In R. V. Kail (Ed.),"Advances in child development and behavior, vol. 31, pp. 43-104, 2003.

[17] Olweus, D., "Bullying at school: What we know and what we can do," Blackwell, Oxford. UK 1993.

[18] Robers, S, Kemp, J, Rathbun, A, \& Morgan, R, "Indicators of school crime and safety: 2013 (NCES 2014-042/NCJ 243299)," National Center for Education Statistics, U.S, Department of Education, and Bureau of Justice Statistics, Office of Justice Programs, U.S. Department of Justice, Washington, DC. 2014

[19] Foley, C. May, D Blevins, R. K, \& Akers, J, "An Exploratory Analysis of Cyber-Harassment of K-12 Teachers by Parents in Public School Settings," Educational Policy DOI: 10.1177/0895904814550071, 2015.

Int. J. Eval. \& Res. Educ. Vol. 8, No. 1, March 2019: 151 - 157 
[20] May, D.C, Johnson, J, Chen, Y, Hutchinson, L, \& Ricketts, M, "Exploringparental aggression toward teachers in a public school setting," Current Issues in Education, vol 13(1), pp. 1-34, 2010.

[21] Jeynes, W. H, "A meta-analysis of the relation of parental involvement tourban elementary school student academic achievement," Urban Education, vol 40, pp. 237-269, 2005.

[22] Attanucci, J. S, "Questioning honor: A parent-teacher conflict over excellenceand diversity in a USA urban high school," Journal of Moral Education, vol 33, pp. 57-69, 2004.

[23] Wong, S. W. D, H. Choon, C. Cheng, "Cyberbullying perpetration and victimization among adolescents in Hong Kong,"Children and Youth Services Review, vol 36, pp. 133-140, 2014.

[24] Barker, I, "Are we ready for parents to watch our lessons by webcam?," Times Educational Supplement, vol 4805, pp. 20-21, Retrieved from EBSCOhost, 2008.

[25] Matsui, J, "Bullying in the workplace survey," [Online] [Available], ttp://www.osstf.on.ca/adx/aspx/adxGetMedia.aspx?DocID=703,687,686,534,442, 2005.

[26] Association of Teachers and Lecturers, "Fifteen percent of teachers haveexperienced cyberbullying," [Online] [Available], http://www.atl.org.uk/media-office/media-archive/cyberbullying-survey.asp, 2009.

[27] Smith, A, "Cyberbullying affecting $17 \%$ of teachers, poll finds," [Online] [Available], http://www.guardian.co.uk/education/2007/jan/19/schools.uk, 2007.

[28] Williams, R, "Teachers suffer cyberbullying by pupils and parents," [Online] [Available], http://www.guardian.co.uk/education/2010/mar/30/teachers-bullied-online, 2010.

[29] Smith, P. K, Mahdavi, J, Carvalho, M, Fisher, S, Russell, S, \& Tippett, N, "Cyberbullying: Its nature and impact in secondary school pupils," Journal of Child Psychology and Psychiatry, vol 49, 2008.

[30] Hinduja, S. and Patchin, J. W, "Cyberbullying: An exploratory analysis of factors related to offending and victimization," Deviant Behavior, vol 29, pp. 1-29, 2008.

[31] Slonje, R. and Smith, P. K, "Cyberbullying: Another main type of bullying?," Scandinavian Journal of Psychology, vol 49(2), pp. 147-154, 2008.

[32] Williams, K. R. and Guerra, N. G, "Prevalence and predictors of internet bullying," Journal of Adolescent Health, vol 41, 2007.

[33] Patchin, J. W. and Hinduja, S, "Bullies move beyond the schoolyard: A preliminary look at cyber bullying," Youth Violence and Juvenile Justice, 4, 2006.

[34] Syts, Y, "Beyond the Schoolyard: Examining Electronic Bullying Among Canadian Youth," Unpublished master's thesis, Carleton University, Ottawa, Ontario, 2004.

[35] Tosun, N, "Cyberbully and Victim Experiences of Pre-Service Teachers," European Journal of Contemporary Education, vol 15(1), pp. 136-146, 2016.

[36] O‘Shaughnessy, J. A, "Is cyber-bullying the next "columbine": Can New Hampshire schools prevent cyber-bullying and avoid liability?," New Hampshire Bar Journal, Spring 2011, 2011.

[37] Horowitz, M, "Educator experiences with and reactions to uncomfortable anddistracting e-mails (Doctoral dissertation, University of Pennsylvania)," Available from Dissertations and Theses: Full Text, (Publication No. AAT 3374188), 2009.

[38] Arıcak, T, Siyahhan, S, Uzunhasanoğlu, A, Sarıbeyoglu, S, Çıplak, S, Yılmaz, N. \& Memmedova, C, "Cyber bullying among Turkish adolescents," CyberPsychology and Behavior, vol 11(3), pp. 253-61, 2008.

[39] Keith, S. and Martin, M, "Cyber-bullying: creating a culture of respect in a cyber world," Reclaiming Children and Youth, vol 13(4), 2005.

[40] Chou, W. S, Hunt, Y. M, Beckjord, E. B, Moser, R. P, \& Hesse, B. W, "Social media use in the United States: Implications for health communication," Journal of Medical Internet Research, vol 11, pp. 1-28, 2009.

[41] Jones, S and Fox, S, "Generations online in 2009. Washington, DC: PewResearchCenter's Internet and American Life Project," 2009.

[42] Felter, M. E, "Student mathematics achievement test scores, dropout rates, and teacher characteristics," Teacher Education Quarterly, vol 28, pp. 151-168, 2001.

[43] Blatchford, P, Bassett, P, \& Brown, P, "Examining the effects of class size on classroom engagement and teacherpupil interaction: Differences in relation to pupil prior attainment and primary vs. secondary schools," Learning and Instruction, vol 21, pp. 715-730, 2011.

[44] Goffredson, D.C. and Dipietro, S.M, "School Size, Social Capital and Student Victimization," Sociology of Education, vol 84, pp. 69-89, 2011. 